\title{
Pengaruh Level Protein dan Level Suplementasi Ekstrak Daun Katuk (Sauropus androgynus) terhadap Performa Broiler
}

\author{
The Effect of Protein and Supplementation of Katuk (Sauropus androgynus) \\ Extract Leaves Levels on Broiler Performances \\ Erina Nuraini, Warnoto, Urip Santoso \\ Jurusan Peternakan, Fakultas Pertanian, Universitas Bengkulu \\ Jalan WR. Supratman Kandang Limun Bengkulu 38371A \\ Email : erina.nuraini2009@gmail.com
}

\begin{abstract}
ABSTRAK
Pemberian pakan berprotein rendah menurunkan performa ayam broiler. Untuk memecahkan masalah tersebut, maka pakan berprotein rendah perlu ditambahkan ekstrak daun katuk. Daun katuk kaya akan senyawa yang mampu memperbaiki metabolisme zat gizi. Oleh karena itu, penelitian ini bertujuan untuk mengevaluasi pengaruh level protein dan level suplementasi ekstrak daun katuk (EDK) terhadap performa broiler. Penelitian menggunakan 72 ekor broiler umur 20 hari. Menggunakan Rancangan Acak Lengkap pola Faktorial (2x3) dengan tiga ulangan. Faktor A adalah level ekstrak daun katuk 4,5 g/kg dan 9 $\mathrm{g} / \mathrm{kg}$ dan Faktor B adalah level protein 15\%, 17\% dan 19\%. Hasil penelitian menunjukkan bahwa level protein tidak berpengaruh nyata terhadap konsumsi dan konversi pakan $(\mathrm{P}>0,05)$, namun nyata meningkatkan pertambahan berat badan dan konsumsi protein $(\mathrm{P}<0,01)$. Level suplementasi ekstrak daun katuk menunjukkan pengaruh tidak nyata $(P>0,05)$ terhadap konsumsi pakan, konsumsi protein, konversi dan pertambahan berat badan. Tidak terdapat interaksi antara level protein dan level suplementasi ekstrak daun katuk. Simpulan hasil penelitian ini adalah pemberian level protein sampai $17 \%$ mampu mempertahankan performa broiler. Namun, pemberian level protein hingga 15\% dalam ransum menurunkan perfoma broiler dan suplementasi ekstrak daun katuk tidak meningkatkan performa broiler.
\end{abstract}

Kata kunci : ekstrak daun katuk, protein, performa

\begin{abstract}
Low protein containing diet feeding reduced broiler performance. To solve that problem, low protein contaning diet should be supplemented with katuk (Sauropus androgynus) extract Katuk leaves is rich in secondary compounds which have ability to improve metabolism of nutrition. Therefore, the present research was conducted to evaluate the effect of protein levels and supplementation levels of katuk leaves extract on broilers performances. Seventy two 20-d-old broilers were distributed to 6 treatment groups of 3 replicates with 3 birds each. Factorial completely randomized experimental design $(2 \times 3)$ was used in the present study. There were supplementation levels of katuk extract $(4,5 \mathrm{~g} / \mathrm{kg}$ and $9 \mathrm{~g} / \mathrm{kg})$ and three levels of protein $(15 \%, 17 \%$ and 19\%). Experimental results showed that protein levels had no effect on feed intake and feed convertion $(\mathrm{P}>0,05)$, but it significant affected body weight gain and protein intake $(\mathrm{P}<0,01)$. Supplementation levels of katuk extract had no effect on feed intake, protein intake, body weight gain and feed conversion $(\mathrm{P}>0,05)$, and also no interaction was found between protein levels and supplementation levels of katuk extract. In conclusion, protein until 17\% maintained performance of broilers. However, feed $15 \%$ protein containing diets reduced broilers performance. Supplementation of katuk leaves extract did not improve performance of broilers.
\end{abstract}

Key words : katuk leaves extract, protein, performance

\section{PENDAHULUAN}

Seiring peningkatan jumlah

penduduk maka akan meningkatkan

kebutuhan protein hewani, sehingga dibutuhkan jenis protein hewani yang mampu mencukupi kebutuhan tersebut, salah satunya adalah daging broiler. Namun, dewasa ini konsumen 
dihadapkan kepada tingginya harga daging broiler. Meningkatnya harga daging broiler disebabkan salah satunya oleh semakin tinggi biaya produksi karena naiknya biaya pakan. Jika biaya pakan dapat diturunkan, maka akan menurunkan biaya produksi secara nyata sebab biaya pakan memberi kontribusi sekitar 60\%-70\% dari biaya produksi total. Salah satu alternatif untuk menurunkan biaya pakan adalah dengan menurunkan kadar protein dalam pakan karena protein merupakan zat gizi yang mahal dan juga menurunkan tingkat pencemaran ekskresi nitrogen yang berlebihan (Hernandez et al., 2012).

Pemberian pakan dengan protein rendah dapat menyebabkan terganggunya produksi broiler seperti berat badan yang lebih rendah, meningkatnya konsumsi pakan dan juga meningkatkan konversi pakan broiler. Berbeda halnya dengan pemberian dengan protein tinggi, akan meningkatkan performa broiler namun akan menambah biaya pakan bagi peternak. Masalah ini dapat dipecahkan dengan memberi feed supplement yang mampu meningkatkan performa broiler pada protein rendah dalam pakan. Salah satu bahan yang potensial adalah daun katuk (Sauropus androgynus).

Beberapa hasil penelitian menunjukkan bahwa daun katuk (Sauropus androgynus) mempunyai zat gizi tinggi, mengandung zat antibakteri, serta tidak berbahaya bagi kesehatan (Santoso, 2000). Katuk (Sauropus androgynus) merupakan tanaman sayuran yang mengandung kalori $59 \mathrm{kal}$, protein 6,4 g, lemak $1 \mathrm{~g}$, hidrat arang 9,9 g, serat 1,5 g, abu 1,7 g, kalsium $233 \mathrm{mg}$, phosphor $98 \mathrm{mg}$, besi 3,5 mg, karoten $10.020 \mu \mathrm{g}$, vitamin B dan C $164 \mathrm{mg}$, air 81 g. Katuk kering mengandung protein $33,68 \%$ per 100 gram (Aziz dan Muktningsih, 2006). Daun katuk mengandung senyawa metabolik sekunder, yaitu monomethyl succinate, cis-2-methylcyclopenthanol asetate, benzoic acid, phenyl malonic acid, methylpyroglutamate dan 2-pyrolidinone (Agusta et al., 1997). Ditemukan juga 3ethyl-3-hydroxy-5 alpha (steroid), 3,4dimethyl-2-oxocyclopent-3-enylacetic acid, polyunsaturated fatty acids, 9eicosyne, 5,8,11-heptadecatrienoic acid ethyl ester, dan 11,14,17-eicosantrienoic acid methyl ester (Suprayogi, 2000). Senyawa-senyawa tersebut sangat penting dalam metabolisme lemak, karbohidrat dan protein dalam tubuh. Pakan dengan suplementasi ekstrak daun katuk dengan level protein rendah diharapkan mampu memberikan pengaruh terhadap performa broiler.

Menurut Santoso dan Sartini (2001) pemberian tepung daun katuk tua sebesar 3\% dalam pakan ternyata dapat 
meningkatkan pertumbuhan dan meningkatkan efisiensi penggunaan pakan, serta Subekti (2003) menunjukkan bahwa pemberian tepung daun katuk $6 \%$ dan $9 \%$ dapat meningkatkan konsumsi pakan ayam lokal. Demikian juga halnya, pemberian ekstrak daun katuk sebanyak 4,5 g/liter air minum ternyata dapat meningkatkan efisiensi pakan dan performa ayam terbaik (Santoso et al., 2001). Santoso et al. (2005) menemukan pemberian ekstrak daun katuk pada ayam petelur menurunkan konversi pakan dan meningkatkan pertambahan berat badan. Dengan memberikan ekstrak daun katuk pada ayam pedaging melalui ransum, ditemukan bahwa suplementasi ekstrak daun katuk sebanyak $18 \mathrm{~g} / \mathrm{kg}$ ransum meningkatkan efisiensi penggunaan ransum dan cenderung meningkatkan pertambahan berat badan dengan income over feed cost tertinggi (Santoso, 2001). Dengan demikian perlu dilakukan penelitian tentang pengaruh dari level protein dan level suplementasi EDK terhadap performa broiler.

Penelitian ini bertujuan mengevaluasi pengaruh level protein dan suplementasi ekstrak daun katuk serta interaksinya terhadap performa broiler. Level protein dan suplementasi ekstrak daun katuk diharapkan dapat meningkatkan performa broiler dan diduga terdapat interaksi antara level protein dengan suplementasi ekstrak daun katuk dalam meningkatkan performa broiler.

\section{MATERI DAN METODE}

Penelitian ini dilaksanakan mulai bulan April sampai dengan bulan Mei 2013 di Commercial Zone Animal Laboratory (CZAL) Jurusan Peternakan Fakultas Pertanian Universitas Bengkulu.

Peralatan yang digunakan dalam penelitian ini antara lain timbangan Ohaus, timbangan $5 \mathrm{~kg}$, tempat pakan, tempat minum, ember, gayung, sekop, dan lain-lain yang dianggap perlu.Bahan pakan yang digunakan antara lain : Jagung kuning, dedak, konsentrat broiler, mineral mixuture, garam dapur, top mix, dan minyak. Ternak yang digunakan adalah ayam broiler umur 20 hari sebanyak 72 ekor yang sebelumnya dipelihara dari DOC dengan diberikan pakan komersil.

\section{Tahapan Penelitian}

Daun katuk dikering-anginkan sampai kering. Setelah kering daun direbus pada suhu $90^{\circ} \mathrm{C}$ selama 20 menit dimana perbandingan daun katuk dengan air adalah 1:5. Setelah itu, hasil rebusan disaring. Ekstraksi dilakukan dua kali. Hasil saringan kemudian dikeringkan pada suhu $55^{\circ} \mathrm{C}-60^{\circ} \mathrm{C}$ selama 36 jam (Santoso et al., 2002). 
Kandang yang digunakan adalah kandang berpetak dengan ukuran panjang : lebar : tinggi adalah $1 \mathrm{~m}: 1 \mathrm{~m}: 60 \mathrm{~cm}$ sebanyak 18 petak dan setiap petak kandang berisi 4 ekor broiler. Sebelum pemeliharaan dilakukan pengapuran pada lantai dan dinding kandang dan bahan litter yang digunakan adalah serbuk kayu setebal $5 \mathrm{~cm}$.

Penelitian ini menggunakan broiler umur 20 hari (periode finisher). Ransum yang digunakan mengandung berbagai level protein kasar (19\%, 17\%, dan 15\%). Sebelum berumur 20 hari, broiler dipelihara dengan pakan komersial.

Rancangan yang digunakan adalah Rancangan Acak Lengkap pola Faktorial $(2 \times 3)$ dengan tiga ulangan. Dimana faktor A yaitu 4,5 gr/ $\mathrm{kg}$ dan 9 $\mathrm{gr} / \mathrm{kg}$ dan faktor $\mathrm{B}$ adalah level protein yaitu $19 \%, 17 \%$ dan $15 \%$.

Kombinasi perlakuan sebagai berikut:

A1B1 = Penambahan ekstrak daun katuk

$4,5 \mathrm{~g} / \mathrm{kg}$, level protein $19 \%$

A1B2 = Penambahan ekstrak daun katuk

$4,5 \mathrm{~g} / \mathrm{kg}$, level protein $17 \%$

A1B3 = Penambahan ekstrak daun katuk

$4,5 \mathrm{~g} / \mathrm{kg}$, level protein $15 \%$

A2B1 = Penambahan ekstrak daun katuk

$9 \mathrm{~g} / \mathrm{kg}$, level protein $19 \%$

A2B2 = Penambahan ekstrak daun katuk

$9 \mathrm{~g} / \mathrm{kg}$, level protein $17 \%$
A2B3 = Penambahan ekstrak daun katuk $9 \mathrm{~g} / \mathrm{kg}$, level protein $15 \%$

Pemberian EDK sebanyak 4,5 $\mathrm{g} / \mathrm{kg}$ dalam ransum berdasarkan hasil penelitian Santoso et al. (2004). Peneliti tersebut menunjukkan bahwa level tersebut mampu meningkatkan performa broiler. Variabel yang diamati adalah konsumsi pakan, konsumsi protein, pertambahan berat badan dan konversi pakan.

\section{HASIL DAN PEMBAHASAN}

Hasil sidik ragam menunjukkan bahwa level protein berpengaruh tidak nyata terhadap konsumsi pakan $(\mathrm{P}>0,05)$. Hasil ini bertentangan dengan Sidadolog (2006) yang menemukan bahwa pemberian pakan berprotein rendah $15 \%$ meningkatkan konsumsi pakan agar kebutuhan protein dapat tercapai. Hal ini diduga pengaruh serat kasar dalam pakan berprotein rendah yang menyebabkan tingkat konsumsi pakan menurun. Serat kasar kaya akan lignin dan selulosa sehingga sulit dicerna broiler (Amrullah, 2002). Pada Tabel 2 menunjukkan kandungan serat kasar pada ransum $15 \%$ lebih tinggi yaitu $4,17 \%$ dibanding protein $17 \%$ dengan serat kasar $3,38 \%$ dan protein $19 \%$ dengan serat kasar $3,05 \%$. 
Tabel 1. Pengaruh level protein terhadap performans broiler

\begin{tabular}{l|c|c|c|c}
\hline Variabel & $19 \%$ & $17 \%$ & $15 \%$ & $\mathrm{P}$ \\
\hline $\begin{array}{l}\text { Konsumsi pakan } \\
\text { (g/ekor) }\end{array}$ & $3702,2 \pm 263,7$ & $3605 \pm 359,7$ & $3342,9 \pm 85,4$ & $\mathrm{~ns}$ \\
$\begin{array}{l}\text { Konsumsi protein } \\
\text { (g/ekor) }\end{array}$ & $703,4 \pm 50,1^{\mathrm{a}}$ & $612,9 \pm 61,1^{\mathrm{b}}$ & $501,4 \pm 12,8^{\mathrm{c}}$ & $\mathrm{P}<0,01$ \\
$\begin{array}{l}\text { Pertambahan berat } \\
\text { badan (g/ekor) }\end{array}$ & $1337,4 \pm 127,1^{\mathrm{a}}$ & $1307,5 \pm 116,9^{\mathrm{a}}$ & $1102,1 \pm 86,2 \mathrm{~b}$ & $\mathrm{P}<0,01$ \\
\begin{tabular}{l} 
Konversi pakan \\
\hline
\end{tabular} & $2,8 \pm 0,4$ & $2,8 \pm 0,2$ & $3,1 \pm 0,2$ & $\mathrm{~ns}$ \\
\hline
\end{tabular}

Keterangan : superskrip yang berbeda pada baris yang sama menunjukkan berbeda sangat nyata $(\mathrm{P}<0,01), \mathrm{ns}=$ non significant

Hasil sidik ragam menunjukkan bahwa level protein berpengaruh sangat nyata $\quad(\mathrm{P}<0,01) \quad$ terhadap konsumsi protein. Konsumsi protein tertinggi terdapat pada level protein $19 \%$. Hal ini didukung dengan jumlah konsumsi pakan yang juga tinggi pada protein $19 \%$. Hal ini sesuai dengan pendapat Malheiros et al. (2003) yang menyatakan bahwa semakin rendah kandungan protein pakan semakin rendah juga konsumsi protein. Fadilah (2004) menyatakan bahwa ternak memenuhi kebutuhan akan protein terutama dari kandungan protein yang terdapat dalam pakan, sehingga tingkat protein pakan yang tinggi akan memberikan konsumsi protein yang tinggi.

Tabel 2. Pengaruh suplementasi ekstrak daun katuk terhadap performans broiler

\begin{tabular}{l|c|c|c}
\hline Variabel & $4,5 \mathrm{~g} / \mathrm{kg}$ & $9 \mathrm{~g} / \mathrm{kg}$ & $\mathrm{P}$ \\
\hline $\begin{array}{l}\text { Konsumsi pakan } \\
\text { (g/ekor) }\end{array}$ & $3540,1 \pm 202,6$ & $3560,0 \pm 257,0$ & $\mathrm{~ns}$ \\
$\begin{array}{l}\text { Konsumsi protein } \\
\text { (g/ekor) }\end{array}$ & $604,2 \pm 104,2$ & $607,6 \pm 103,6$ & $\mathrm{~ns}$ \\
$\begin{array}{l}\text { Pertambahan berat } \\
\text { badan (g/ekor) }\end{array}$ & $1273,2 \pm 102,7$ & $1224,7 \pm 153,5$ & $\mathrm{~ns}$ \\
Konversi pakan & $2,8 \pm 0,2$ & $2,9 \pm 0,2$ & $\mathrm{~ns}$ \\
\hline
\end{tabular}

Keterangan $: \mathrm{ns}=$ non significant

Sidik ragam menunjukkan level protein berpengaruh sangat nyata $(\mathrm{P}<0,01)$ terhadap pertambahan berat badan broiler. Pertambahan berat badan pada level protein $19 \%$ berbeda tidak nyata $(\mathrm{P}>0,05)$ jika dibandingkan dengan protein $17 \%$, sedangkan protein $15 \%$ sangat nyata $(\mathrm{P}<0,01) \quad$ menurunkan pertambahan berat badan. Turunnya pertambahan berat badan pada level protein $15 \%$ disebabkan oleh turunnya konsumsi protein. Penggunaan level protein yang berbeda dapat mempengaruhi pertumbuhan broiler, pasokan energi dan protein yang cukup 
penting untuk perkembangannya (Sidadolog, 2006).

Hasil sidik ragam menunjukkan bahwa level protein berpengaruh tidak nyata $(\mathrm{P}>0,05)$ terhadap konversi pakan. Standar protein pada broiler adalah 19\% untuk fase finisher (NRC, 1994). Penggunaan level $17 \%$ protein lebih efisien dibanding level 19\% karena memiliki nilai konversi yang sama yaitu 2,8 . Keuntungan yang diperoleh akibat penurunan level protein ini yaitu terjadi penurunan biaya produksi dari 19\% protein ke $17 \%$ protein dan kemungkina akan terjadi penurunan tingkat pencemaran akibat ekskresi nitrogen.

Tabel 3. Pengaruh interaksi level protein dan suplementasi ekstrak daun katuk terhadap performans broiler

\begin{tabular}{|c|c|c|c|c|c|c|}
\hline Variabel & $19 \%$ & Protein & $17 \%$ & Protein & $15 \%$ & protein \\
\hline & $4,5 \mathrm{~g} / \mathrm{kg}$ & $9 \mathrm{~g} / \mathrm{kg}$ & $4,5 \mathrm{~g} / \mathrm{kg}$ & $9 \mathrm{~g} / \mathrm{kg}$ & $4,5 \mathrm{~g} / \mathrm{kg}$ & $9 \mathrm{~g} / \mathrm{kg}$ \\
\hline $\begin{array}{l}\text { Konsumsi } \\
\text { pakan } \\
\text { (g/ekor) }\end{array}$ & $\begin{array}{c}3773,6 \pm \\
248,5\end{array}$ & $\begin{array}{c}3630,8 \pm \\
278,9\end{array}$ & $\begin{array}{c}3435,8 \pm \\
273,3\end{array}$ & $\begin{array}{c}3774,2 \pm \\
446,1\end{array}$ & $\begin{array}{c}3410,8 \pm \\
111,0\end{array}$ & $\begin{array}{c}3275,0 \pm \\
59,7\end{array}$ \\
\hline $\begin{array}{l}\text { Konsumsi } \\
\text { protein } \\
\text { (g/ekor) }\end{array}$ & $\begin{array}{c}717,0 \pm \\
47,2\end{array}$ & $\begin{array}{c}689,9 \pm \\
53,0\end{array}$ & $\begin{array}{c}584,1 \pm \\
46,5\end{array}$ & $\begin{array}{c}641,6 \pm \\
75,8\end{array}$ & $\begin{array}{c}511,6 \pm \\
16,7\end{array}$ & $\begin{array}{c}491,3 \pm \\
9,0\end{array}$ \\
\hline $\begin{array}{l}\text { Pertambaha } \\
\text { n berat } \\
\text { badan } \\
\text { (g/ekor) }\end{array}$ & $\begin{array}{c}1346,4 \pm \\
146,2\end{array}$ & $\begin{array}{c}1328,3 \pm \\
108,0\end{array}$ & $\begin{array}{c}1317,5 \pm \\
49,9\end{array}$ & $\begin{array}{c}1297,5 \pm \\
183,8\end{array}$ & $\begin{array}{c}1155,8 \pm \\
73,5\end{array}$ & $\begin{array}{c}1048,3 \pm \\
98,8\end{array}$ \\
\hline $\begin{array}{l}\text { Konversi } \\
\text { pakan }\end{array}$ & $2,8 \pm 0,4$ & $2,8 \pm 0,4$ & $2,6 \pm 0,2$ & $2,9 \pm 0,1$ & $3,0 \pm 0,3$ & $3,1 \pm 0,2$ \\
\hline
\end{tabular}

Keterangan : Baris yang tidak memiliki superskrip menunjukkan berbeda tidak nyata $(\mathrm{P}>0,05)$.

Nilai konversi pakan perlakuan dengan protein rendah akan lebih tinggi 3,2 dibandingkan dengan perlakuan protein pakan sedang 2,7 dan tinggi 2,5 (Sidadolog dan Yuwanta, 2009). Amrullah (2002) menyebutkan bahwa semakin rendah angka konversi pakan berarti kualitas pakan semakin baik

Level suplementasi ekstrak daun katuk menunjukkan berpengaruh tidak nyata terhadap konsumsi pakan $(\mathrm{P}>0,05)$. Pada Tabel 3 menunjukkan penggunaan ekstrak daun katuk 4,5g/kg lebih baik dibanding $9 \mathrm{~g} / \mathrm{kg}$. Hasil ini sama dengan Santoso et al. (2001) yang menemukan bahwa pemberian ekstrak daun katuk 4,5 g lebih baik dibanding ekstrak daun katuk $3,0 \mathrm{~g}$ dan $1,5 \mathrm{~g}$. Hal ini berarti katuk 4.5 $\mathrm{g} / \mathrm{kg}$ menunjukkan level suplementasi terbaik terhadap konsumsi pakan.

Hasil sidik ragam menunjukkan level suplementasi ekstrak daun katuk berpengaruh tidak nyata $(\mathrm{P}>0,05)$ terhadap konsumsi protein. Hasil ini sama dengan Jaspin (2012) menemukan pakan yang mengandung tepung daun 
katuk tidak berpengaruh nyata terhadap konsumsi protein.

Hasil sidik ragam menunjukkan level suplementasi ekstrak daun katuk berpengaruh tidak nyata $(\mathrm{P}>0,05)$ terhadap pertambahan berat badan. Pertambahan berat badan pada suplementasi ekstrak daun katuk level 4,5 $\mathrm{g} / \mathrm{kg}$ cenderung lebih tinggi dibanding level 9 g/kg. Santoso et al. (2004) menyatakan suplementasi ekstrak daun katuk dapat meningkatkan pertambahan berat badan dengan level 4,5 g/kg. Lebih rendahnya pertambahan berat badan pada level $9 \mathrm{~g} / \mathrm{kg}$ diduga kandungan tanin dan saponin lebih banyak yang dapat menghambat penyerapan protein dalam tubuh sehingga menyebabkan pertambahan berat badan menurun. Tanin menyebabkan gangguan pada proses pencernaan dalam saluran pencernaan sehingga menurunkan pertumbuhan. Selain itu, saponin meningkatkan permeabilitas sel mukosa usus halus yang berakibat penghambatan transport nutrisi aktif dan menyebabkan penyerapan protein dan zat-zat gizi dalam saluran pencernaan menjadi terganggu (Syah, 2011).

Hasil sidik ragam menunjukkan bahwa level suplementasi ekstrak daun katuk berpengaruh tidak nyata $(\mathrm{P}>0,05)$ terhadap konversi pakan. Konversi pakan dengan ekstrak daun katuk 4,5 g/kg lebih baik dari ekstrak daun katuk 9 g/kg. Hal ini sama dengan Santoso et al. (2004) yang menemukan suplementasi ekstrak daun katuk dengan level 4,5 g/kg menunjukkan konversi pakan terbaik.

Tidak terdapat interaksi antara level protein dan suplementasi ekstrak daun katuk terhadap konsumsi pakan dan konsumsi protein. Hal ini berarti tidak terjadi sinergitas untuk protein dan ekstrak daun katuk dalam meningkatkan konsumsi pakan dan konsumsi protein.

Analisis ragam pertambahan berat badan menunjukkan bahwa suplementasi ekstrak daun katuk dan level protein tidak saling berinteraksi. Hal ini menunjukkan ransum dengan berbagai level protein yang disuplementasi ekstrak daun katuk tidak dapat meningkatkan pertambahan berat badan broiler.

Tidak terdapat interaksi antara level protein dan suplementasi ekstrak daun katuk terhadap konversi pakan. Hal ini menunjukkan pakan dengan level protein rendah yang disuplementasi ekstrak daun katuk tidak dapat mempengaruhi konversi pakan

\section{KESIMPULAN}

Berdasarkan hasil penelitian disimpulkan bahwa penggunaan pakan level $15 \%$ protein menurunkan performa broiler. Pemakaian level protein 19\% dapat diturunkan menjadi $17 \%$ protein tanpa mempengaruhi performa broiler 
fase finisher. Tidak terdapat interaksi antara level protein dan suplementasi ekstrak daun katuk dalam meningkatkan performa broiler.

\section{DAFTAR PUSTAKA}

Agusta, A., Harapini dan Chairul. 1997. Analisis kandungan kimia ekstrak daun katuk (Sauropus androgynus(L) Merr) dengan GCMS. Warta Tumbuhan Obat, 3 (3):31-33.

Amrullah, I. K. 2002. Nutrisi Ayam Broiler. Lembaga Satu Gunungbudi, Bogor.

Aziz, S. dan S. R. Muktningsih. 2006. Studi manfaat daun katuk (Sauropus androgynus). Cermin Dunia Kedokteran 151 (50) : 4850.

Fadilah, R. 2004. Ayam Broiler Komersial. Agromedia Pustaka, Jakarta.

Hernandez, E., M. Lopez, S. Martinez, M. D. Megias, P. Catala and J. Madrid. 2012. Effect of lowprotein diets and single sex on production performance, plasma metabolites, digestibility, and nitrogen excretion in 1-to 48-dayold broilers. Poultry Science, 91: 683-692.
Jaspin, S. H. 2012. Konsumsi dan rasio efisiensi protein pada broiler yang mendapat ransum mengandung berbagai level tepung daun katuk (Sauropus androgynus). Laporan penelitian. Fakultas Peternakan Universitas Hasanuddin. Makassar.

Kumar, V., A. V. Elangovan, and A. B. Mandal. 2005. Utilization of reconstitued high-tanin sorghum in the diets of broiler chicken. Journal of Animal Science, 18 (4): 538-544.

Malheiros, R. D., M. B. Moraes, A. Collin, P. J. Janssens, E. Decuypere and J. Buyse. 2003. Dietary macronutrients and endocrine functioning and intermediary metabolism in broiler chickens. Nutrion Research. $23: 567-578$.

Santoso, U. 2000. Mengenal daun katuk sebagai feed additive pada broiler. Poultry Indonesia 242: 59-60.

Santoso, U. 2001. Effect of Sauropus androgynus Extract on the performance of broiler. Buletin Ilmu Peternakan dan Perikanan 7: $15-21$

Santoso, U. and Sartini. 2001. Reduction of fat accumulation in broiler chickens by Sauropus androgynus 
(katuk) leaf meal

supplementation. Asian-

Australasian Journal of Animal

Science. 14: 346-350.

Santoso, U., J. Setianto dan T. Suteky. 2002. Penggunaan ekstrak daun katuk untuk meningkatkan efisiensi produksi dan kualitas telur yang ramah lingkungan pada ayam petelur. Laporan Penelitian Hibah BersaingUniversitas Bengkulu, Bengkulu.

Santoso, U., J. Setianto and T. Suteky. 2005. Effect of Sauropus androgynus (Katuk) extract on egg production and lipid metabolism in layers. AsianAustralasian Journal of Animal Science. 18 (3): 364-369).

Santoso, U., Suharyanto and E. Handayani. 2001. Effects of Sauropus androgynus (Katuk) leaf extract on growth, fat accumulation and fecal microorganisms in broiler chickens. JITV 6 (4): 220-226.

Santoso, U., Y. Fenita dan W. G. Wiranda. 2004. Penggunaan ekstrak daun katuk untuk memproduksi meat designer. Laporan Penelitian. Universitas Bengkulu, Bengkulu.

Sidadolog, J. H. P. 2006. Penyesuaian waktu pemberian pakan dan kandungan protein-energi yang berbeda terhadap efisiensi pakan dan pertumbuhan ayam broiler. Buletin Peternakan: Yogyakarta $30(3): 23-37$.

Sidadolog, J. H. P and T. Yuwanta.2009. Effect of protein-energi concentration in feed on body weight gain, energy and proteinefficiency in the growth period of Merawang chicken. Journal of Animal Production: Yogyakarta 11 (1) 15-22

Subekti, S. 2003. Kualitas telur dan karkas ayam lokal yang diberi tepung daun katuk dalam ransum. Tesis. Institut Pertanian Bogor. Bogor.

Suprayogi, A. 2000. Studies on the biological effets of Sauropus androgynus (L) Merr: effects on milk production and the possibilities of induced pulmonary disorder in lactating sheep. Cuviller Verlag Gottingen. 